\title{
Biofertilizers: A novel tool for agriculture
}

\author{
Boraste A. ${ }^{1}$, Vamsi K.K. ${ }^{2}$, Jhadav A. ${ }^{3}$, Khairnar Y. ${ }^{3}$, Gupta N. ${ }^{5}$, Trivedi S. ${ }^{4}$, Patil P. ${ }^{6}$, Gupta G. ${ }^{7}$, \\ Gupta M. ${ }^{5}$, Mujapara A.K. ${ }^{8}$, Joshi B. ${ }^{9}$ \\ ${ }^{1}$ S.V.P.M. College of Pharmacy, Baramati, Pune \\ ${ }^{2}$ Rai foundations College CBD Belapur Navi Mumbai \\ ${ }^{3}$ Padmashree Dr. D.Y. Patil University, Navi Mumbai, 400614, India \\ ${ }^{4}$ V.V.P. Engineering College, Rajkot, Gujrat \\ ${ }^{5}$ Sindhu Mahavidyalaya Panchpaoli Nagpur \\ ${ }^{6}$ Dr. D. Y. Patil ACS College, Pimpri, Pune \\ ${ }^{7}$ S.D.S.M. College Palghar, Mumbai \\ ${ }^{8}$ Sir PP Institute of Science, Bhavnagar, Gujrat, adarshmujapara@gmail.com \\ ${ }^{9}$ Rural College of Pharmacy, D.S Road, Bevanahalli, Banglore
}

\begin{abstract}
With the increasing demand in agriculture it has become important for us to increase the productivity by using various fertilizers insecticides Pesticides. But with the tremendous use of these products the soil has been affected badly because of the depletion in the essential minerals of the soil. So to overcome this problem it has become important for all of us touse a different remedy for the production of various biofertilizers. The production if such biofertilizers from various microorganisms was studied from this work.
\end{abstract}

\begin{abstract}
Introduction
About 100 years ago, Hellriegal and Wilfarth demonstrated clearly that fixation of atmospheric nitrogen takes place in legumes, although earlier in 1980s, Boussingault, a French agriculturist, provided the data to show that legumes are superior to cereals in furnishing the nitrogen to plant. Beijerinck, a Dutch scientist, in 1888 isolated root nodule bacteria, (Rhizobium) from root nodules of legumes and that the time many other have defined. Bio-fertilizers, in strict sense, are not fertilizers, which directly give nutrition to crop plants. These are cultures of microorganisms like bacteria, fungi, packed in a carrier material. Thus, the critical input in biofertilizer is the microorganisms. They help the plants indirectly through better Nitrogen (N) fixation or improving the nutrient availability in the soil. The term "Biofertilizer" or more appropriately a "Microbial inoculants" can generally be defined as preparation containing live or latent cells of efficient strains of Nitrogen fixing, Phosphate solublising or cellulolytic microorganisms used for application to seeds, soil or composting areas with the objective of increasing the number of such microorganisms and accelerate those microbial process which augment the availability of nutrients that can be easily assimilated by plants. Biofertilizer can provide an economically viable support to small and marginal farmers for realizing the ultimate goal of increasing productivity. Biofertilizer are low cost, effective and renewable source of plant nutrients to supplement chemical fertilizers. Microorganisms, which can be used as biofertilizer, include bacteria, fungi and blue green algae. These organisms are added to the rhizosphere of the plant to enhance their activity in the soil. Sustainable crop production depends much on good soil health. Soil health maintenance warrants optimum combination of organic and
\end{abstract}

inorganic components of the soil. Repeated use of chemical fertilizers destroys soil biota. In nature, there are a number of useful soil microorganisms that can help plants to absorb nutrients. Their utility can be enhanced with human intervention by selecting efficient organisms, culturing them and adding them to soils directly or through seeds. The cultured microorganisms packed in some carrier material for easy application in the field are called biofertilizers. Bio-fertilizers are living microorganisms of bacterial, fungal and algae origin. Their mode of action differs and can be applied alone or in combination. By systematic research, efficient strains are identified to suit to given soil and climatic conditions. Such strains have to be mass multiplied in laboratory and distributed to farmers. They are packed in carrier materials like peat, lignite powder in such a way that they will have sufficient shelf life. The list of commonly produced bio-fertilizers in our country is shown in Table no 1. The biofertilizer are mainly purchased by State Agriculture Departments and distributed to the farmers at concessional rates. About 200 to 500 grams of carrier material is only needed per acre, costing about Rs.10/- to 25/-. The current trends indicate that there is a steady increase in the demand in the Southern states except Andhra Pradesh, Western States and Madhya Pradesh and Rajasthan.

\section{Decomposing Culture}

Composting is a process essentially meant to utilize soil waste of animal-plant origin. Composting procedure can be hastened by inoculating the residue with cellulolytic - lignolytic microorganisms such as Trichoderma viridae, Aspergillus niger, Aspergillus terrus etc. The improvement in soil fertility due to sludge 
application was reflected through population diversity of soil microbial community. The technologies used were indigenous and Agricultural Universities and Research Laboratories of GOI standardize the scientific aspects of production. Machineries and laboratory equipments are available from various manufacturers and are of BIS standards. The primary objective of biofertilizer projects could be production of various strains of good quality biofertilizer using most modern technology. The infrastructure and laboratory facilities created, however, can be utilized for the production of bio - pesticides and bio control agents. Multi product range will increase the viability. In line with the technology and objective of biofertilizer production, various facilities are required for the successful implementation of such projects .From foregoing paragraphs, it is cleared that two organisms, via a nitrogen fixer and a phosphate solubilizers can be mixed and applied. Composite cultures containing both nitrogen-fixer and phosphate solubilizers are an area that holds considerable importance. Attempts were made to prepare a biofertilizer from forest waste using EM solution (effective microorganism). Forest waste like weeds, stalks, stems, fallen leaves, pruning, dead branches and grass clippings, old flowers, green pruning etc. EM solution contains combination of Phototrophic Bacteria, Lactic acid bacteria and Yeast. Photosynthetic bacteria synthesize useful substances from secretions of roots, organic matter and/or harmful gases (e.g. hydrogen sulfide), by using sunlight and the heat of soil as sources of energy. Lactic acid bacteria produce lactic acid from sugars and other carbohydrates, developed by photosynthetic bacteria and yeast. Yeast synthesizes antimicrobial and other useful substances required for plant growth from amino acids and sugars secreted by photosynthetic bacteria, organic matter and plant roots.

\section{Materials and Methods \\ Preparation of biofertilizer}

All organic material wastes available on a forest, such as weeds, stalks, stems, fallen leaves, pruning, and dead branches were collected. Hard woody material such as dead branches and pigeon pea stalks were first crushed with the help of crusher machine before being piled. Material composts best when it is $1.25-3.75 \mathrm{~cm}$ in size. Soft, succulent tissues did not need chopping into very small pieces because they decompose rapidly. The harder or woodier the tissues, the smaller they need to be in order to decompose rapidly. Chopping material with a sharp shovel is effective, when pruning plants, the material were cut into small pieces using the pruning shears. This requires a little effort but the results are worth it. For the composting process to work most effectively, the material to be composted should have a C: $\mathrm{N}$ ratio of $20: 1$. Mixing equal volumes of green plant material with equal volumes of naturally dry plant material yields such a ratio. The green material can be grass clippings, old flowers, green pruning, weeds, fresh garbage and fruit and vegetable wastes. The dried material can be fallen leaves, dried grass, and woody material from pruning. All the ingredients are mixed together, except accelerator (EM solution). These grind particle mix with soil (soil used because soil has ability to absorb moisture and provided suitable condition for growth of microorganism) mix the mixture uniformly. 2. Pit site and size: -The site of the compost pit was taken a level high enough to prevent rainwater from entering in the monsoon season; a temporary shed was to be constructed over it to protect the compost from heavy rainfall and to avoid direct contact of environmental heat during summer. The pit was made about $1 \mathrm{~m}$ deep, 1.5-2 $\mathrm{m}$ wide and of a suitable length can vary according to the availability of land. The pit was having a slant walls and floor with $90-\mathrm{cm}$ slope to prevent water logging. 3. Filling the pit:Before making first pile in the pit, base of the pit was sprinkled with water so that it will help in maintain optimum temperature for the growth of microorganism. Adding Organic residues form first pile with soil in pit. A unit pile is about $5 \mathrm{~m}$ (length) $\times 1 \mathrm{~m}$ (width) $\times 1 \mathrm{~m}$ (height) in size. The pile is sprinkled with water for adequate moisture content and EM solution (from maple orgtech India Itd, kolkata) is sprinkled on it. This procedure is repeated until the pit is full. The pit is covered with a plastic sheet. To maintain the moisture condition daily adequate amount of water is added around the pit, this continues for two to three weeks. After two or three weeks later, the whole pile was mixed in order to boost aerobic decomposition. 4. The pile was turned: The pile was turned after two weeks and then again after another week. Normally, the compost is ready after two weeks when the heap has cooled down and the height of the pile has fallen to about $70 \mathrm{~cm}$.

\section{Methods of Analysis Of Organic Fertilizer}

1. Estimation of pH: $25 \mathrm{~g}$ compost was mixed with $50 \mathrm{ml}$ of distilled water and kept on rotary shaker for 2 hours. Filtrate was obtained through Whatman filter paper under vacuum using a funnel. $\mathrm{pH}$ of filtrate is determined using $\mathrm{pH}$ meter.

2. Estimation of moisture:- $5 \mathrm{gm}$ of prepared compost was taken on a dry petri-dish. It was heated in an oven for about 5 hours at $65 \square \mathrm{C}$, constant weighing was done. Cooling is done in a desicator and weigh. Percentage loss in weight was estimated as moisture content of the Biofertilizer.

Calculation of Moisture:-

Moisture percent by weight $=100(B-C) / B-A$ 
3. Estimation of bulk density: Weight of dry 100$\mathrm{ml}$ cylinder was taken (W1 gm).100ml of sample was taken in the cylinder to note the volume (V1ml).Cylinder along with the sample was weighted by using weighing machine (W2 gm).The cylinder is tapped for two minutes. Volume was measured after tapping (V2 $\mathrm{ml}$ ).

Calculation of bulk density

$$
\text { Bulk density }=\frac{\text { weight of the sample taken (W2-W1) }}{\text { Volume (V2-V1) }}
$$

4. Estimation of electric conductivity: Fresh sample of organic fertilizer was passed through a $2-4 \mathrm{~mm}$ sieve. $20 \mathrm{gm}$ of the sample is added to $100 \mathrm{ml}$ of distilled water to it to give a ratio of 1:5.Stirring is done for about an hour at regular intervals. Calibrate the conductivity meter by using 0.01 potassium chloride solution (of AR grade).Using conductivity meter (SVG Electronics Ltd) conductivity of the unfilled organic fertilizer suspension was measured.

5. Estimation of Organic Carbon: Reagents:-

1. Phosphoric acid (ortho)-85\%

2. Sodium fluoride solution $-2 \%$

3. Sulphuric acid AR-96 \% containing 1.25\% Ag2SO4.

4. Standard IN K2Cr2O7, dissolve $49.04 \mathrm{gm}$ $\mathrm{K} 2 \mathrm{Cr} 2 \mathrm{O} 7$ in water and is diluted to 1 litre.

5. Standard 0.5 N Ferrous ammonium sulphate

6. Diphenylamine indicator

Grind air-dry compost and sieve with 80 meshes ( $2 \mathrm{~mm}$ sieve). $0.5 \mathrm{gm}$ sample in $500 \mathrm{ml}$ conical flask is added. Later $50 \mathrm{ml}$ of $\mathrm{K} 2 \mathrm{Cr} 2 \mathrm{O} 7$ with burette and swirl a little. Then $50 \mathrm{ml}$ conc. $\mathrm{H} 2 \mathrm{SO} 4$ is added and swirl again 2-3 times. It is been kept standing for 30 minutes in dark place and thereafter $200-\mathrm{ml}$ of water is added. Then the volume is made up to $500 \mathrm{ml}$ in a volumetric flask. Out of this $50 \mathrm{ml}$, an aliquot (equivalent to $0.1 \mathrm{gm}$ sample) was taken in another $500 \mathrm{ml}$ conical flask. $15 \mathrm{ml}$ of orthophosphoric acid and 1 $\mathrm{ml}$ of Diphenylamine was used as an indicator. Titration is done with 0.5 ferrous ammonium sulphate till the colour flashes blue violet to green. Simultaneously runs a blank without compost sample.

\section{Calculation of Organic Carbon}

Organic carbon $\%=\frac{10(\mathrm{BT})}{\mathrm{B}} \times 0.003 \times \frac{100}{\text { Weight of sample }} \times 1.3$

6. Estimation of nitrogen by Kjeldahl's method reagents

1. $0.02 \mathrm{~N} \mathrm{H} 2 \mathrm{SO} 4$

2. $40 \%$ sodium hydroxide

3. $2 \%$ boric acid indicator

4. Mixed indicator

1. Digestion:-

$200 \mathrm{mg}$ of the compost sample was taken in a 50-

$\mathrm{ml}$ digestion flask, and then $5 \mathrm{ml}$ of $\mathrm{H} 2 \mathrm{O} 2$ and 5 $\mathrm{ml} \mathrm{H} 2 \mathrm{SO} 4$ was slowly added. It is then kept in the digestion chamber for 24 hours. If any sample remained black or yellow, then few drops of $\mathrm{H} 2 \mathrm{O} 2$ was added to find a clear solution. Then transfer the digested sample to a $100 \mathrm{ml}$ volumetric flask \& make the volumetric with distilled water.

Distillation procedure: - Distillation apparatus was set up. Connections were fixed air tight. Heating is started and simultaneous addition of $10 \mathrm{ml}$ of $40 \% \mathrm{NaOH}$ and $10 \mathrm{ml}$ of the plant aliquot in a distillation chamber through a funnel provided with an apparatus. The nitrogen escaped in the form of ammonia is collected in a $10 \mathrm{ml}$ boric acid indicator. With the collection of ammonia, the colour of the boric acid turns green. Ammonia (nitrogen) escaped is collected from the process and it may be tested with a red litmus paper. Titration is done against $0.02 \mathrm{~N} \mathrm{H} 2 \mathrm{SO} 4$. Calculation of nitrogen by Kjeldahl's method:-

Percentage of nitrogen $=$ Burette reading $\times 0.02 \times 0.014 \times \frac{100}{10} \times \frac{100}{0.2}$

$=$ Burette reading- Blank reading $x 1.14$

7. Estimation of phosphorus by klett summerson method

Reagent

1. Vanado-molybdate nitric acid reagent

2. Standard phosphorus solution

Preparation of standard curve- $0,1,5,10,15 \& 20$ $\mathrm{ml}$ is pipette out of the stock solution and each of them is kept in $50 \mathrm{ml}$ volumetric flask. $10 \mathrm{ml}$ of Vanado-molybdate reagent is added to make up the volume up to the mark with distilled water. It gives $0,5,10,15,20 \mathrm{ppm}$ of phosphors. Intensity is read of the yellow colour or at colorimeter at $470 \mathrm{~nm}$ wavelength.

Digestion- 200mg of the compost sample is taken in a $50-\mathrm{ml}$ digestion flask. $5 \mathrm{ml}$ of $\mathrm{H} 2 \mathrm{O} 2$ and $5 \mathrm{ml}$ $\mathrm{H} 2 \mathrm{SO} 4$ is added slowly. It is then kept in the digestion chamber for 24 hours. If any sample remains black or yellow, few drops of $\mathrm{H} 2 \mathrm{O} 2$ is added to make a clear solution. The digested samples are transferred to a $100 \mathrm{ml}$ volumetric flask \& make the volumetric with distilled water.

Procedure- $10 \mathrm{ml}$ of the biofertilizer (sample) aliquot is pipette out in a $50-\mathrm{ml}$ volumetric flask.10ml vanando-molybdate reagents are added and diluted till $50 \mathrm{ml}$ with addition of distilled water. After two minutes, it is observed at $470 \mathrm{~nm}$ wavelength. Workout the ppm of the phosphorus of the sample from the standard $\mathrm{X}$ curves.

Calculation of Phosphorus by Klett Summerson Method

Percent of phosphorous $=\frac{\mathrm{X}}{1000,000} \times 50 \times \frac{100}{10} \times \frac{100}{0.2}$

Percent of phosphorous $=X \times 0.25$

$X-p p m$ of phosphorus read from the standard curve.

$\mathrm{X}-3.8 \mathrm{ppm}$ 
8. Estimation of potassium by flame photometer method reagent:-Stock solutions of potassium Preparation of standard curve:-0, 1, 2, 4, 6, 8 and $10 \mathrm{ml}$ of stock solution is pipette out in $100-\mathrm{ml}$ volumetric flask. The volume is marked up to the mark with addition of distilled water. It gives 0 , $10,20,40,60,80$, and $100 \mathrm{ppm}$ of potassium respectively. The intensity of potassium at flame photometer is observed. The sample is aliquot directly with a flame photometer. Work out the ppm of potassium form the standard curve run a blank reading.

Calculation of potassium by Flame photometer method

Percentage of potassium $=\frac{\mathrm{X}}{1000,000} \times 100 \times \frac{100}{0.2}$

$=0.05 \times X$

$X$ - ppm of potassium read from the standard curve

$\mathrm{X}-30 \mathrm{ppm}$

\section{Eestimation of heavy metal atomic absorption spectroscopy}

1. Sampling- Approximately $50 \mathrm{gm}$ of sample was taken. Then the samples were air dried for a period to remove excess moisture. Air dried sample are then passed through $0.5 \mathrm{~mm}$ sieve. The sample passing through the sieve is mixed and used to obtain the analytical sample. 2 . Sample treatment for total element determination- About 1gm of the sieved sample was accurately weight and it was transfer to a $100 \mathrm{ml}$ beaker. From a measuring cylinder about $20 \mathrm{ml}$ of $1: 1$ nitric acid and is boiled gently on a hot plate until the volume of nitric acid is reduced to about $5 \mathrm{ml}$. Addition of about $20 \mathrm{ml}$ of deionized water in the sample and boil gently again until the volume is approximately $10 \mathrm{ml}$. The suspension is cooled and filtered through a whatman filter paper, then the beaker and filter paper is washed with small portion of de-ionized water until a volume of about $25 \mathrm{ml}$ is obtained. The filtrate is then transferred to a $50 \mathrm{ml}$ graduated flask and make up to the mark with deionized water.

\section{Observation}

Observation during preparation of material:Material composts best when it is $1.25-3.75 \mathrm{~cm}$ in size. Soft, succulent tissues do not need chopping into very small pieces because they decompose rapidly. Hard woody material such as dead branches and pigeon pea stalks has to crushed with the help of crusher machine before being piled so it help to microorganism to decompose material rapidly. Observation during filling of first pile in pit (first day):-Before making first pile in the pit, base of the pit should be sprinkled with water so that it will helps in maintaining optimum temperature for the growth of microorganism. Observation on second day:The pit is covered with a plastic sheet. To maintain the moisture condition, daily adequate amount of water was added around the pit, this is continued for two to three weeks. Observation on fourth day:- On fourth day, temperature of the pit is higher then the pervious observation. Raising of temperature shows that microorganism start there work of decomposing organic material. Observation on seventh day:-After one week later, the whole pile is mixed in order to boost aerobic decomposition. During seventh day in some area of pit, decomposition of organic material is observed. It indicates that microorganism fully start there work of composting. Observation on fourteen day (second week):-The pile is again turned after two weeks. During fourteen-day the rapid decomposition can be detected by a pleasant odour, by the heat produced (visible in the form of water vapour given off during the turning of the pile), by the growth of white fungi on the decomposing organic material, by a reduction of volume, and by the materials changing colour to dark brown. As composting nears to completion, the temperature drops. Observation on twentyone day (third week): On twenty-one day, height of the pile has fallen to about $70 \mathrm{~cm}$. and little or no heat is observed. Temperature of pit drops to normal condition. It shows that biofertilizer is fully prepared from organic forest waste.

\section{Results}

After 21 days of composting, normally, biofertilizer is ready. When the heap has cooled down and the height of the pile has fallen to about $70 \mathrm{~cm}$. By analysis result we can confirm that the biofertilizer contains all essential nutrients which are required for plant growth. This shows that microorganisms totally brake down complex organic material waste into simple organic material. It further indicates that, we successfully prepared the biofertililizer from the forest waste using EM (effective microorganism) solution.

\section{Discussion}

Biofertilizers enhance the nutrient availability to crop plants (by processes like fixing atmosphere $\mathrm{N}$ or dissolving $\mathrm{P}$ present in the soil); and impart better health to plants and soil thereby enhancing crop yields in a moderate way. It is a natural method without any problems like salinity and alkalinity, soil erosion etc.. In the vast areas of low input agriculture and oil seeds production, as also in crops like sugarcane, etc, these products will be of much use to give sustainability to production. In view of the priority for the promotion of organic farming and reduction of chemical residues in the environment, special focus has to be given for the production of biofertilizers. No hazardous effluents are 
generated from a biofertilizer unit. A versatile material, biofertilizer benefits virtually any soil type. Clay soil, for example, has tiny, tightly packed particles that hamper the flow of water, nutrients, and oxygen. Biofertilizer reconfigures the clay into larger, more loosely packed particles. The larger spaces between the particles improve the flow of water, oxygen, and nutrients to roots. In addition, the roots are able to penetrate deeper into the soil and contact more nutrients. Biofertilizer also improves sandy soil, where the large spaces between loosely packed particles enable water and its dissolved nutrients to drain too quickly for optimum root absorption. Biofertilizer soaks up and holds these substances so that the roots have more time to absorb them. Biofertilizer also adds small amounts of zinc, copper, boron, and other vital nutrients to soils. Protect water quality. Because the composting process converts nitrogen into a less soluble form, it is less likely to be washed out of manure and into ground water and surface water. Excessive amounts of nitrate in drinking water can cause health problems such as blue baby syndrome and may be linked to cancer and birth defects. Recent samplings of wells in northern Whatcom County have found nitrate levels above the U.S. Environmental Protection Agency's safe drinking water standards. Using compost instead of chemical fertilizers can reduce our use of non-renewable resources like natural gas. Approximately two percent of the natural gas consumed in the United States goes into the manufacturing of nitrogen fertilizer. Our rate of waste production can no longer be adequately dealt with by natural decomposition processes. Land filling is a crisis of urban centres world wide. We need to engineer new bio-decomposition processes. To do this is conceptually simple but will take much greater interaction between ecologists and engineers Essentially what needs to happen is to match up all the various types of organic wastes with their decomposers. We must learn how to culture a wide variety of bacterial, fungal, and invertebrate organisms in high-density, optimal configurations to achieve rapid, clean, bio-conversion, and biodetoxification of waste into compost (soil amendment) and useful biomass for biochemical's, feed and food. Each of the major advances in organization of life on earth have involved symbiotic associations in which more ancient bio-metabolic capabilities were linked with more recent bio-mechanical or bio-social organizations. For example the eukaryotic cell was assembled from prokaryotic elements which became such cell organelles as mitochondria and chloroplasts (endosymbiosis) (Margulies, 1998). Higher (vascular) plants are usually dependent directly or indirectly on bacterial and fungal symbioses such as nitrogen fixing root and leaf nodules and fungal mycorrhizae. Animals from the simplest nematode worms to humans harbor all kinds of microbial symbionts, especially those in the guts which are essential for digestion, nutrition (intestinal symbiosis) and microbial health. Agriculture and animal husbandry are really no more than the selective identification of a few key organisms which we have learned to symbiosis with, by culturing them. We now need to learn how to grow (culture) a lot of smaller, complex communities of micro- organisms and insects, and we need to do this on a big scale if we are to avert the looming ecological crisis which faces the human population on a finite planet. Waste management is not something that can be left to mechanical engineers and chemists. Sewage treatment, composting, manure management, plowing under crop stubble, and site preparation after logging are all examples of the presently haphazard activities which involve crude efforts toward decomposer management. The major organisms that need to be studied are those of the decomposer and detrital food chains. We have traditionally neglected these organisms as useless within a productive context although they constitute the bulk of biodiversity. Instead our culturing and production systems concentrate on a select number of trees, herbs and herbivore animals. The bacteria, fungi, and insects are mainly looked upon as pests and pathogens which we have diligently attempted to control, if not eradicate. Some of the essential organisms with which we must now seek to symbiosis include the methanogenic archaebacteria, the thermophilic and actinomycetes composting bacteria, the wood degrading basidiomycetes and the terrestrial oligochaete annelid worms, the profoundly important lignocelluloses and humus consuming termites, and the enormously diverse coleopteran consumers of moist to dry organic materials, and the hordes of fly maggots that inhabit every form of sodden and anaerobic organic matter. Some key organisms already being cultivated are red wriggler worms, Ensenia foetida; and the black soldier fly, Hermetia illucens. Red wriggler earth worms are widely used for "vermicomposting"in kitchen compost boxes for vegetative food scraps. Black soldier flies, formerly the most abundant flies in human privies, are now widely used for manure management programs. Waste management engineers are not going to be able to do this on their own. Highly specialized biological knowledge is necessary. Biologists must identify the key organisms and provide the essential information about the organisms' ecology and physiology. Decompiculture will become a major new applied field in the biological sciences. Within the next hundred years, Decompiculture is inevitable. 


\section{Conclusion}

The compost material used was of the size of $1.25-3.75 \mathrm{~cm}$. From this we conclude that hard woody material used in the compost should be crushed with the help of crusher machine, so it will help microorganism to compost material rapidly. To maintain $\quad \mathrm{C}: \mathrm{N}$ ratio as $20: 1$ of the biofertilizer the material used in the pile should have equal volumes of green plant material with equal volumes of naturally dry plant material to yields such a ratio. Small amount of soil is mix with the material so it helps to maintain moisture condition and provided suitable condition for growth of microorganism. A temporary shed may be constructed over pit to protect the compost to avoid direct contact of environmental heat during summer. The pit should have sloping walls and floor with $90-\mathrm{cm}$ slope to prevent water logging. Before making first pile in the pit, base of the pit should be sprinkled with water so that it will help in maintain optimum temperature for the growth of microorganism. Sprinkling EM solution on material accelerating the breakdown of organic matter from forest waste and required less time than natural process of composting; used of EM solution in biofertilizer preparation help to increase the number of beneficial microorganisms in the soil, this improves the soil's microbial health and promotes a healthy environment for plants.

$\mathrm{pH}$ reading conclude that biofertilizer almost alkaline in nature, after moisture estimation we conclude that biofertilizer have very good capacity to maintain moisture condition. Bulk density estimation we conclude that biofertilizer have very good capacity to hold water, which give indication of standard biofertilizer. The electric conductivity estimation we conclude that biofertilizer contain less salt concentration. Biofertilizer have C: $N$ ratio 20:1 and which further indicates the stability of biofertilizer. C:N ratio less than 25 likely indicates that composting process is finished. Complete decomposition of material and high level of nutrient present in the material. Biofertilizer contain the less amount of heavy metal.

\section{References}

[1] Alagwadi and Gaur (1988) Trees, crops and soil fertility: concepts and research methods. CABI Publishing, ISBN0851995934.
[2] Community Sanitation and Recycle Organization (CSARO). Web site: http://www.bigpond.com.kh/users/csaro/

[3] Cracas P. (2000) Vermicomposting"in Cuban style. Worm Dig. Iss. 25 -online articles.

[4] Jambhhekar H. (2002) Vermiculture in India - online training material. Pune, India, Maharashtra, Agricultural Bioteks.

[5] Natural Resource, Agriculture, and Engineering Service (NRAES) (1992) On-farm composting, edited by $R$. Rynk. Ithaca, USA, NRAES Cooperative Extension.

[6] Ndegwa P.M. and Thompson S.A. (2001) Biores. Tech., 76(2): 107-112.

[7] Palm C.A., Gachengo C.N., Delve R.J., Cadisch G. andller, K.E. (2001) Ag. Ecosys. Env., 83: 27-42.

[8] Raabe R.D. (2001) The rapid composting method. University of California, US, Co-operative Extension, Division of Agriculture and Natural Resources.

[9] Ramasami S. (1975) Processing of bones into bonemeal and its effect on plant growth. New Delhi, Indian Agricultural Research Institute. (PhD thesis)

[10] Richard T. (1996) The effect of lignin on biodegradability. In: Cornell composting. (http://www.cfe.cornell.edu/compost/calc /lignin.html)

[11] Schorth G. (2003) Decomposition and nutrient supply from biomass. In $G$. Schorth \& F.L. Sinclari, eds.

[12] Smith R.C. (1995) Composting practices. NDSU Extension Service, North Dakota State University of Agriculture and Applied Science, and USDA.

[13] Suneja (1994) Tamilnadu Agricultural University (TNAU) 1994. Crop production guide. Coimbatore, India.

[14] Subba Rao N S, Oxford \& IBH, New Delhi Biofertilizers in Agriculture and Forestry

[15] Sanoria and Ram (1980) A manual of rural composting. Regional Project RAS/75/004. 
Table 1-Types of Biofertilizer

Rhizobium

Azotobacter

Azospirillum

Blue green Algae

Phosphate solublising

microorganism

Table 2 - Estimated potential Demand for Biofertilizer by 2008-2009

\begin{tabular}{lr} 
Type of Biofertilizer & \multicolumn{1}{c}{ Demand } \\
Rhizobium & 44,999 \\
Azotobacter & 165,953 \\
Azospirillum & 94,342 \\
Blue green Algae & 301,738 \\
Phosphate solublising & 280,340 \\
Total & 756,372
\end{tabular}

Table 3 -list of commonly produced bio-fertilizers in India

\begin{tabular}{|c|c|c|c|}
\hline Name & Crops Suited & Benefits Usually Seen & Remarks \\
\hline $\begin{array}{l}\text { Rhizobium } \\
\text { strains }\end{array}$ & $\begin{array}{l}\text { Legumes like pulses, } \\
\text { groundnut, soybean } \\
\text { Soil treatment for non- }\end{array}$ & $\begin{array}{l}10-35 \% \text { yield increase, } 50- \\
200 \mathrm{~kg} \mathrm{~N} / \mathrm{ha} \text {. }\end{array}$ & $\begin{array}{l}\text { Fodders give better results. Leaves residual } \mathrm{N} \\
\text { in the soil. }\end{array}$ \\
\hline Azotobacter & $\begin{array}{l}\text { legume crops including } \\
\text { dry land crops } \\
\text { Non-legumes like maize, } \\
\text { barley, oats, sorghum, }\end{array}$ & $\begin{array}{l}10-15 \% \text { yield increase- } \\
\text { adds } 20-25 \mathrm{~kg} \mathrm{~N} / \mathrm{ha}\end{array}$ & $\begin{array}{l}\text { Also controls certain diseases. } \\
\text { A fodder gives higher/enriches fodder } \\
\text { response. Produces growth-promoting }\end{array}$ \\
\hline $\begin{array}{l}\text { Azospirillu } \\
\text { m } \\
\text { Phosphate }\end{array}$ & $\begin{array}{l}\text { millet, Sugarcane, rice } \\
\text { etc. }\end{array}$ & $10-20 \%$ yield increase & $\begin{array}{l}\text { substances. It can be applied to legumes as } \\
\text { co-inoculants }\end{array}$ \\
\hline$\underset{*}{\text { Solubilizers }}$ & $\begin{array}{l}\text { Soil application for all } \\
\text { crops }\end{array}$ & $5-30 \%$ yield increase & an be mixed with rock phosphate. \\
\hline
\end{tabular}

( ${ }^{*}$ there are 2 bacterial and 2 fungal species in this group)

Blue-green

algae and

Azolla

Rice/wet lands give biomass up to $40-50$ Tonnes and fix $30-100 \mathrm{~kg}$ $\mathrm{N} / \mathrm{ha}$

Many trees, some crops, $\quad 30-50 \%$ yield increase Mycorrhiza and some ornamental enhances uptake of $\mathrm{P} . \mathrm{Zn}$, e (VAM) plants $\mathrm{S}$ and Water.
Reduces soil alkalinity, can be used for fishes as feed. They have growth promoting hormonal effects.

TNAU has developed high yielding Azolla hybrids.

Usually inoculated to seedlings.

Table 5- analysis result of biofertilizer

$\begin{array}{ll}\text { Compost Analysis } & \text { Results } \\ \text { Estimation of } \mathrm{pH} & 6.75 \\ \text { Estimation of moisture } & 18.18 \% \\ \text { Estimation of bulk density } & 2 \% \\ \text { Estimation of electric conductivity } & 0.559 \text { milliohm's at } 25^{\circ} \mathrm{C} \\ \text { Estimation of organic carbon } & 19.5 \% . \\ \text { Estimation of nitrogen by KJELDAHL'S method } & 1.3 \% . \\ \text { Estimation of phosphorus by KLETT SUMMERSON method } & 0.95 \% . \\ \text { Estimation of potassium by FLAME PHOTOMETER method } & 1.5 \% .\end{array}$


Table 5- analysis result of biofertilizer

Compost Analysis

Estimation of $\mathrm{pH}$

Estimation of moisture

Estimation of bulk density

Estimation of electric conductivity

Estimation of organic carbon

Estimation of nitrogen by KJELDAHL'S method

Estimation of phosphorus by KLETT SUMMERSON method

Estimation of potassium by FLAME PHOTOMETER method
Results

6.75

$18.18 \%$

$2 \%$

0.559 milliohm's at $25^{\circ} \mathrm{C}$

$19.5 \%$.

$1.3 \%$.

$0.95 \%$.

$1.5 \%$.

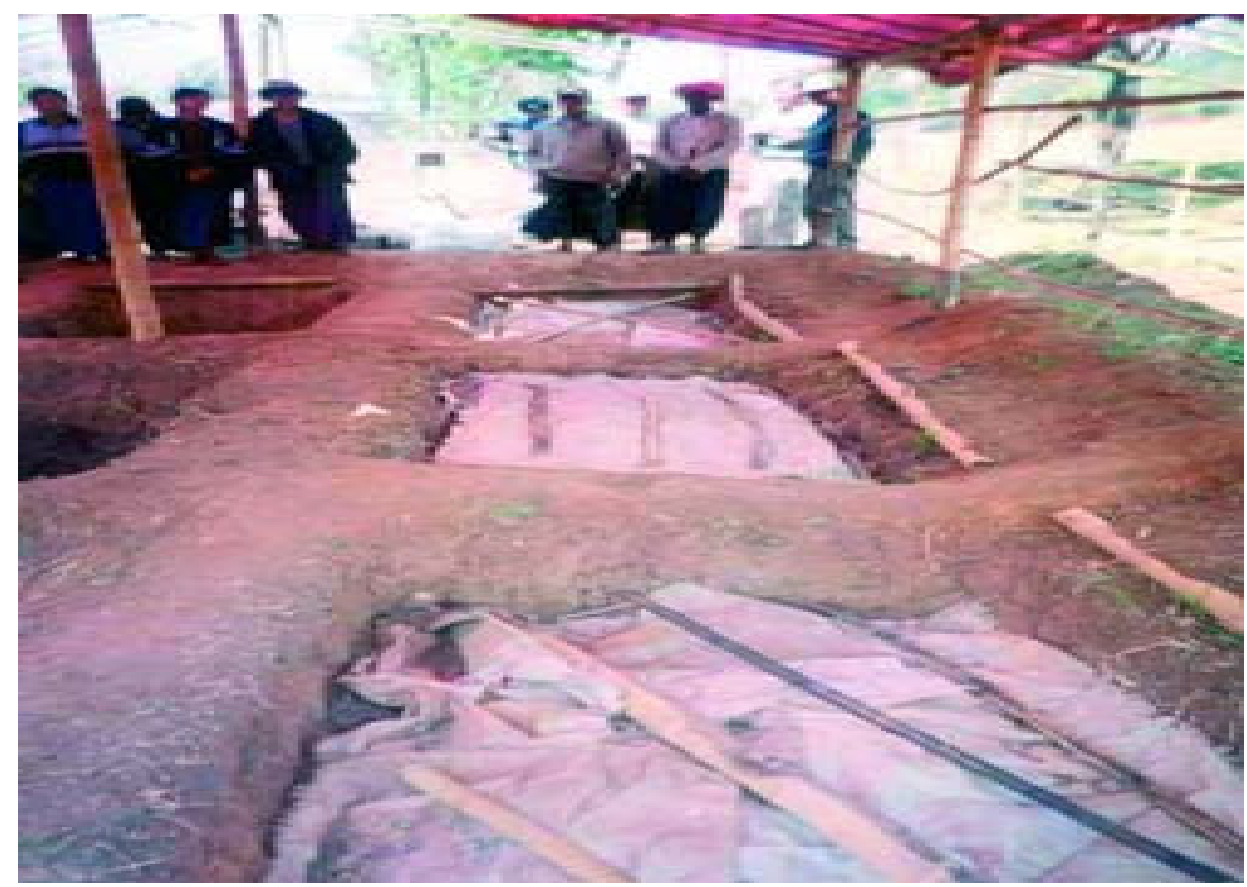

Fig. 1- Compost pits

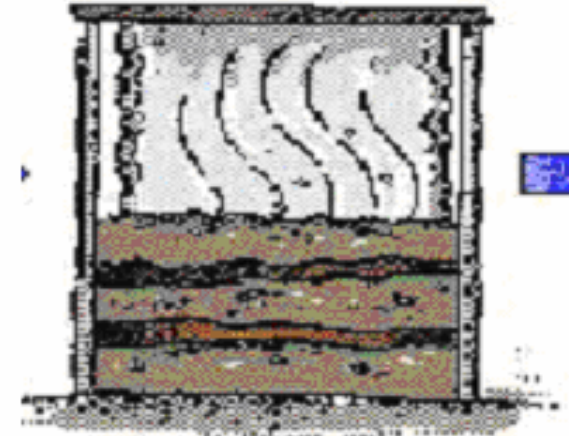

Building up

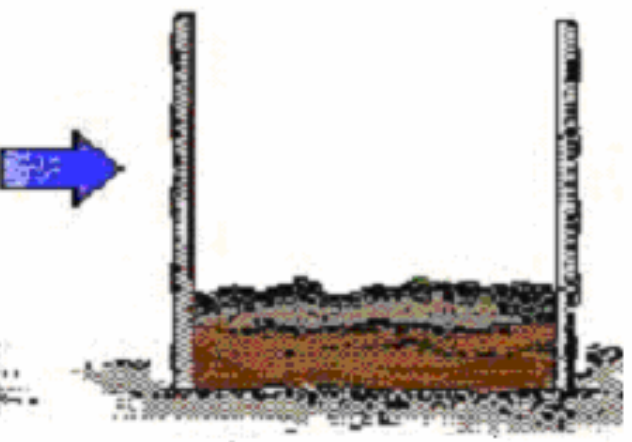

Decompostion

Heat

Fig. 2-Pile after turning 


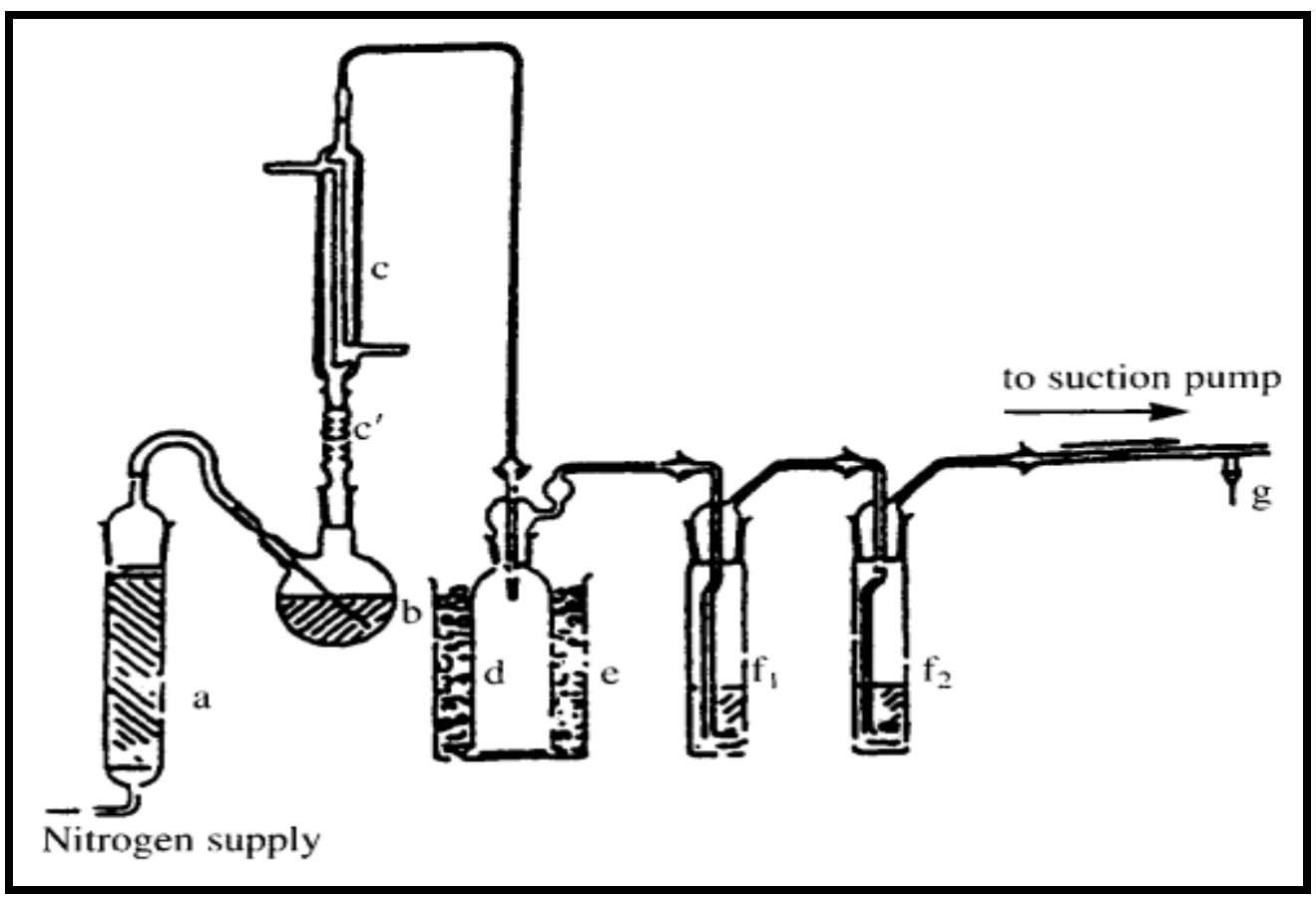

Fig. 3-KJELDAHL'S instrument for nitrogen estimation 